\title{
Alternative sanitary concepts for rural and urban areas
}

\author{
A. Wriege-Bechtold ${ }^{1}$, A. Peter-Fröhlich ${ }^{2} \&$ M. Barjenbruch ${ }^{1}$ \\ ${ }^{1}$ Department of Urban Water Management, \\ Technische Universiät Berlin, Germany \\ ${ }^{2}$ Berliner Wasserbetriebe Berlin, Germany
}

\begin{abstract}
Conventional wastewater treatment is state of the art in Middle Europe. Most of the nutrients in wastewater are removed in wastewater treatment plants, but a part of them is discharged out to our rivers and lakes and can effect eutrophication. In other areas, such as Africa, Asia and South-America, there is little or no treatment of wastewater at all. In particular, rapidly growing megacities have problems with the collection and treatment of incoming wastewater. Sewage systems, if existent, are overloaded. The insufficient sewage purification causes diseases and environmental pollution. Furthermore, there is a scarcity of fresh water and there is not enough fertiliser for agriculture. Alternative sanitary concepts are able to close the loop of water and nutrients and give sanitary comfort to citizens. Novel sustainable wastewater treatment systems take care of the different flows of wastewater, such as greywater, brownwater and yellowwater, in a special and verified way. By using brownwater, it is possible to produce biogas for heating, cooking and power. Greywater can be treated to obtain water for laundry and to flush toilets. Urine is full of nutrients and a perfect substitute for mineral fertiliser. In a project near Berlin, some no-mix toilets are installed in an office and an apartment building. The results of the tests with a biogas plant show good production of biogas and there is a possibility of using bio-waste from households as a co-substrate. The measured values in the treated sludge show that it is possible to use it as a soil conditioner in agriculture. The implementation of such novel sanitary concepts in urban areas is more difficult than in low-density areas, but in general is not impossible.
\end{abstract}

Keywords: alternative sanitary systems, source separation, close the loop, nomix toilets, biogas, fertiliser, save water. 


\section{Introduction}

The drinking water consumption in households is about 125 litres per day in Germany. Most of the water is consumed for uses that do not need drinking water quality. The spread of water use is shown in figure 1.

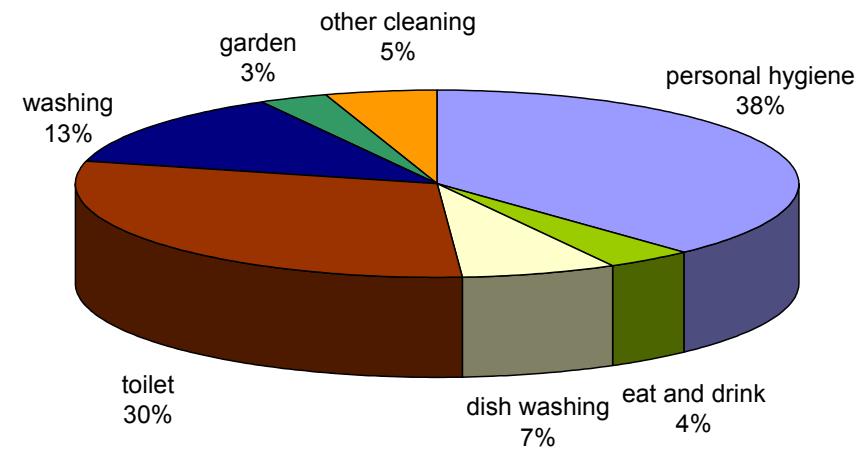

Figure 1: $\quad$ Spread of water use in households in litres per person and day [1], modified.

More than $50 \%$ of this freshwater is substitutable by recycled greywater. Greywater is water from showers, dishwashers, washing machines and hand washbasins as a part of domestic wastewater. In particular, flush water for toilets does not need to be the best freshwater quality. Water for other cleaning, such as windows or outside areas, requires lower water quality. Recycled water is sufficient for watering grassland in the garden. Hygienically, standards have to be kept and it is necessary to have binding definitions.

Usually wastewater is collected in sewer systems and directed to wastewater treatment plants. By use of energy, pollutants and nutrients are reduced but the cleaning is not complete. In agriculture, mineral fertilisers compensate for the need for nutrients. There are a lot of scenarios showing that phosphorous resources will be exhausted within the next 100 years.

At the same time, nearly 1.2 billion people are without safe drinking water. In coming years the worldwide water scarcity will reach Europe too. The aim must be the provision and efficient use of fresh water and other resources.

\section{Waste water treatment, Quo Vadis?}

Currently, domestic wastewater is generated by flushing toilets and from normal outlets in the kitchen, etc., in most industrialised countries. In the so-called endof-pipe-system, used fresh water runs as wastewater through toilets and outlets to the sewer system and finally to a wastewater treatment plant (WWTP). The energy-rich wastewater will be separated from nutrients and pollutants. In WWTPs there is a loss of nutrients and trace elements contained in excrement, but less recycling. A relevant percentage is still in the effluent, which can cause 
eutrophication of surface water bodies. On the one hand, a major problem of conventional waste water systems is the high water consumption of fresh water for transport. On the other hand, the wastewater treatment is energy-intensive, while purification of wastewater causes carbon dioxide emissions.

In Germany there are about 1.5 million kilometres of sewers. Most of them are old and about $20 \%$ [2] of those sewers will need rehabilitation in the short and medium term. At the time of construction, water use and the growth of the population was increasing. However, today there is decreasing water consumption and declining population. Many people save water because of rising water rates. Therewith costs are increased by the need to flush the sewers. WWTPs are under-loaded, therefore the treatment process is suboptimal.

Worldwide 2.5 billion people have no connection to any wastewater treatment and another 2.8 billion people use only simple ditches. About $90 \%$ of wastewater and excreta are only poorly treated or not treated at all. The poor or nontreatment of wastewater cause serious diseases, because raw sewage runs into surface water or directly to agro-fields. Conventional sewer systems are not a sustainable solution for countries with scarcity of drinking water and a lack of nutrients (fertiliser).

Alternative sanitary systems are wastewater collection und treatment technologies, which are more innovative than conventional methods. The main principles of those systems are the reuse of wastewater and nutrients. Therefore the separate collection and specific treatment of the different wastewater flows, such as yellowwater, brownwater (see section 3.1) and greywater, are practised.

To collect the nutrients and energy at their source, it is useful to change the sanitary installations. The different flows are discharged to specialised treatment facilities. It is important that the source is near to the location of treatment in order to minimize costs for the transport of wastewater.

\section{Alternative sanitary systems}

\subsection{Definition}

Yellowwater means urine with or without flush water. Yellowwater is collected in urinals and no-mix toilets. Brownwater is the mixture of faeces and flush water from no-mix toilets. Blackwater is defined as brownwater plus yellowwater. Greywater is the effluent from:

- showers;

- dish washers;

- washing machines;

- hand wash basins.

In Figure 2 loads per capita and day (in percent of total load) are shown.

\subsection{Greywater}

Greywater is volumetrically the largest part of wastewater, but of no major hygienic concern. It contains almost very little nutrients and some chemical residues from washing laundry and dishes and from showers. The treatment of 
greywater is simpler than the treatment of yellow or brownwater. The COD load is $40 \%$ of the total load, but the concentration is low because of high volume. Greywater can be treated by constructed wetlands, membrane reactors or moving bed reactors. Constructed wetlands are low tech but require a lot of space. The treatment of greywater in membrane reactors is high-tech but space saving. Both methods are industrially fully developed and state-of-the-art.

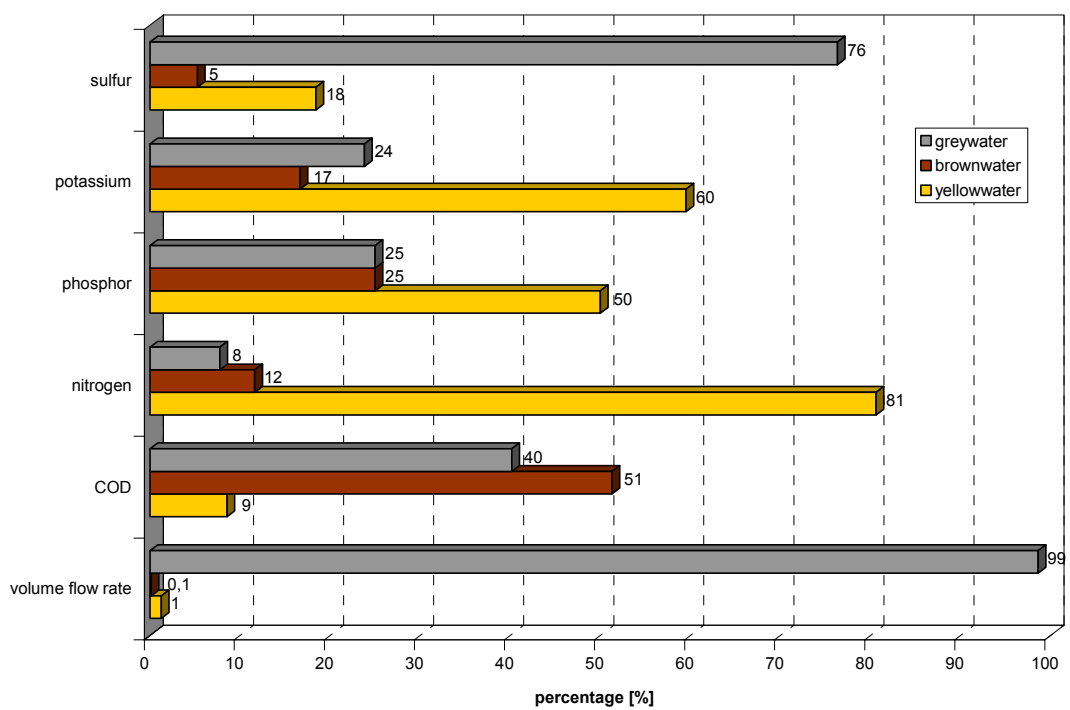

Figure 2: Percentages of different substances of component currents of wastewater [3].

\subsection{Yellowwater}

The largest part of nutrients available to plants is contained in urine. For instance $81 \%$ of the total load of nitrogen is in the yellowwater and almost the comparable highest loads of potassium and sulphur. For its use as fertiliser it is useful to collect the urine without or only with a low volume of flush water. Yellowwater has less hygienically critical components than brownwater, but it may contain hormones or medical residues. Simplest treatment is the storage of yellowwater. At $20^{\circ} \mathrm{C}$ over a period of 6 months no viruses and were detectable [4]. Therefore the treatment of urine is on a technically advanced level. There are different treatment processes successful tested like vacuum evaporisation, steam stripping, precipitation, ozonisation and so on. Most of the yellowwater treatment facilities are tested in pilot plant scale and use a lot of energy at this time. The production of fertiliser from urine is possible.

\subsection{Brownwater}

The brownwater is hygienically critical because of many pathogens. It consists of organics, nutrients and trace elements and is energy-rich. The volume of 
brownwater depends on the kind of installed toilets (see Table 1). Suitable treatment possibilities for brownwater are (vermicular-) composting and anaerobic digestion. Composting is low tech and requires a lot of space. Digestion is technical treatment with energy use. Because of flush water content, brownwater mostly needs pre-treatment. After treatment brownwater improves soil quality and capillary capacity.

Table 1: $\quad$ Kinds of toilet and corresponding volumes of flow [5], modified.

\begin{tabular}{|c|c|}
\hline Type of toilet & $\underline{\text { Advantages }+/ \text { Disadvantages - }}$ \\
\hline Flush toilet & $\begin{array}{l}+ \text { simple construction } \\
- \text { high volume of flush water } \\
- \text { no reuse of water }\end{array}$ \\
\hline Vacuum toilet & $\begin{array}{l}+ \text { state of the art } \\
- \text { high complexity } \\
+ \text { low consumption of flush water }\end{array}$ \\
\hline No-mix toilet & $\begin{array}{l}+ \text { low consumption of flush water } \\
+ \text { small-scale dilution } \\
+ \text { reuse of nutrients possible }\end{array}$ \\
\hline Vacuum no-mix toilet & $\begin{array}{l}\text { + low consumption of flush water } \\
\text { - high complexity } \\
+ \text { reuse of nutrients possible } \\
\text { - test stage }\end{array}$ \\
\hline Waterless urinal & $\begin{array}{l}+ \text { increasing extension } \\
\text { - increasing maintenance effort } \\
\text { - only for males }\end{array}$ \\
\hline
\end{tabular}

\section{Application of alternative sanitary systems for urban areas}

\subsection{Growth of population}

In 1950 there were only 8 cities with more than 5 million inhabitants (and only one with more than 10 millions). In 2000 there were about 40 cities, 16 with more than 10 million inhabitants [6]. Prognosticates that in the year 2015 nearly 60 cities will have more than 5 million inhabitants - among them 21 cities with more than 10 million inhabitants. The number of people living in urban areas will increase especially in least developed countries by $4 \%$ per year in the period from 2005 to 2010 . Enormous efforts must be made in these regions to provide everybody a primary sanitation.

\subsection{Scenario for alternative sanitary systems in a multi-storey building}

As already mentioned most experiences with alternative sanitary systems are only for sparsely populated areas, because of high requirement of space for instance by constructed wetlands. With new technologies like membrane reactors 
they seem to be applicable also in industrialised countries. An implementation of alternative sanitary systems in multi-storey buildings of urban areas could be practicable.

In the basement of a multi-storey building treatment plants can be integrated. The nutrient-rich yellowwater will be collected in tanks. After treatments such as steam-stripping or ozonisation, the yellowwater can be used on urban greens, on acreage for renewable primary products or in fertiliser plants. With renewable primary products biogas can be generated in digesters.

The brownwater can be treated by fermentation in a biogas plant. The biowaste from the flats can also be used for biogas production. Bio waste is collected by a separate collection system or directly disposed into the toilets. The fouled stained sludge from the biogas plant can be applied to fertilise renewable primary products outside of the city. The produced biogas will be charged and is applicable for cooking, heating, hot water etc.

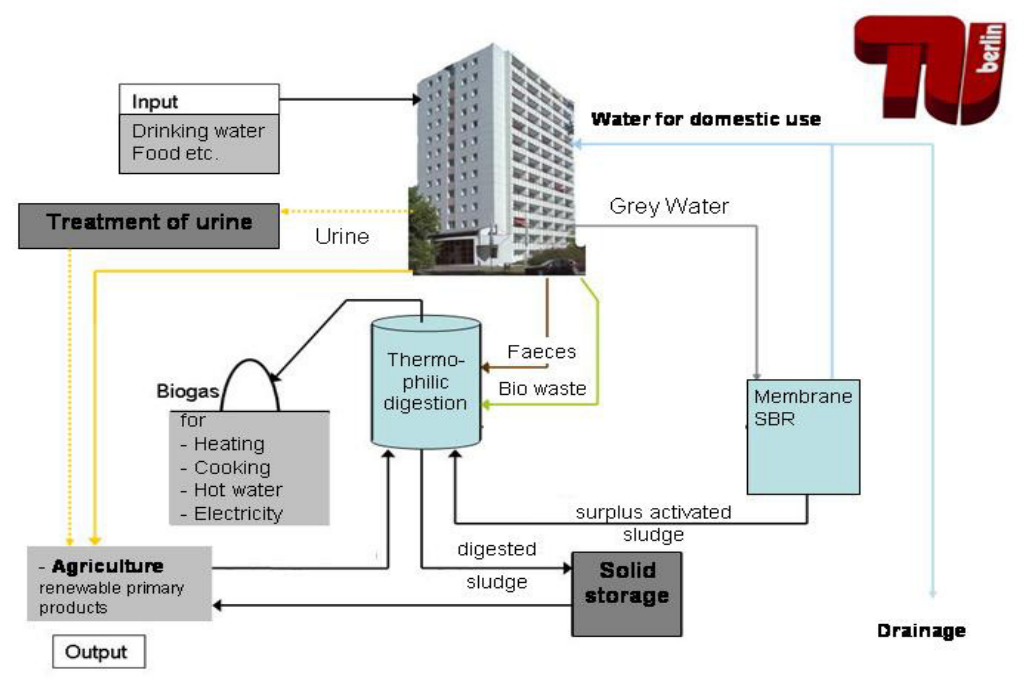

Figure 3: Possibility of implementation of novel sanitary systems in multistorey-buildings.

The greywater will be purified in a Sequencing-Batch-Reactor (SBR) or membrane plant and can be charged in reservoirs with the additionally collected storm water from house roofs. This so called water for domestic use can be utilized e.g. for flushing toilets. The excess sludge from the greywater treatment can be returned to the biogas plant.

Alternatively it is possible to integrate the biogas plants into existing pumping stations if there is not enough space in the basement of the buildings. In case of low connection values this solution is always thinkable. In the planning horizon of new buildings extra space must be considered. 
At the moment this system only exists in parts but not as a whole working system. Therefore a pilot installation with such modern treatment concept is important for introduction.

\section{SCST-project in Stahnsdorf/Germany}

Such new sanitation concepts for the separate discharge and treatment of yellowwater, brownwater, and greywater were installed and implemented in previously existing buildings (one office building and one two-storey apartment house) on the grounds of the wastewater treatment plant Stahnsdorf nearby Berlin. The new sanitation concept in the office building was installed in $2002 / 2003$ when the building was being renovated. In spring 2005, the new concept was extended to the apartment house (see Figure 4).

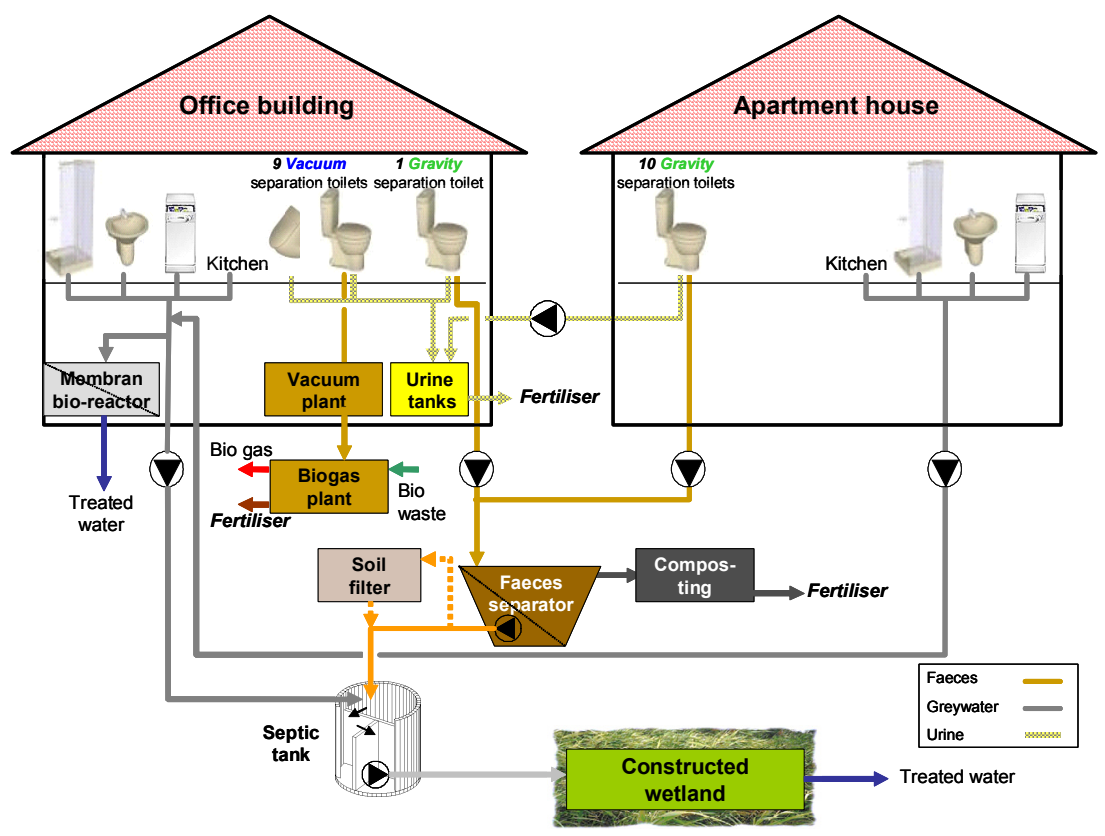

Figure 4: Tested sanitation concepts (left: vacuum separation toilets; right: gravity separation toilets).

In the sanitation concept featuring gravity separation toilets (see Figure 5), the brownwater was discharged by gravity, dewatered in filter bags, and subsequently thickened.

The thickened faeces were then composted. The filtrate was channelled into a two-chamber septic tank for pre-treatment. The greywater was also pre-treated mechanically in the septic tank. The mixture of mechanically treated greywater and faeces filtrate then underwent biological treatment by means of a constructed wetland. Simultaneously, the biological treatment of the greywater by a 
membrane bio-reactor was tested. The treated greywater from both installations (constructed wetland, membrane bio-reactor) can be used e.g. for irrigation purposes.
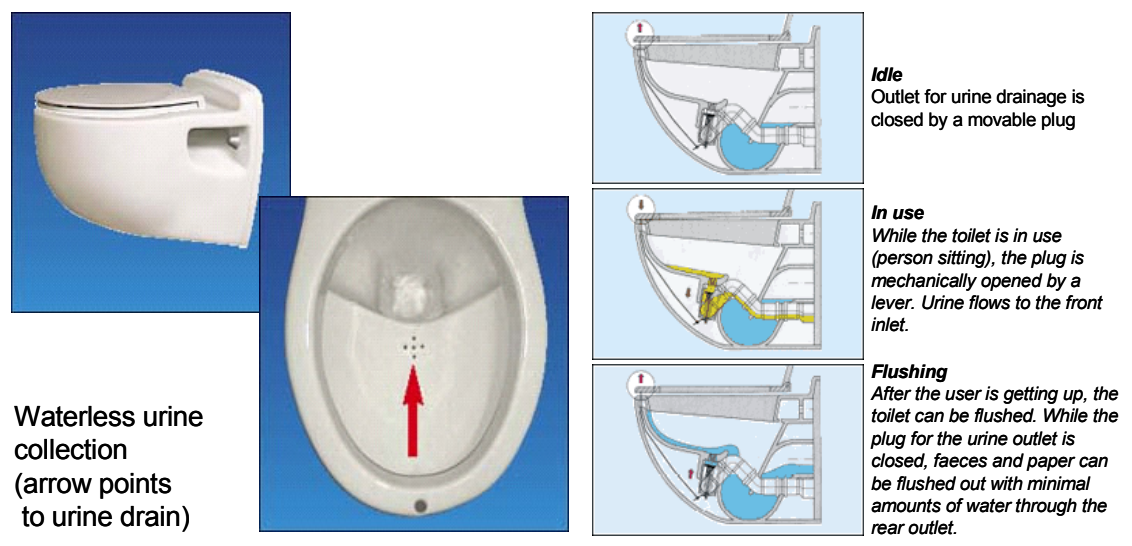

Figure 5: Gravity separation toilet (no-mix toilet) from the company Roediger [7].

The yellowwater was discharged into tanks through a separate pipe. As part of the project, tests regarding fertilising potential with the yellowwater took place. In addition to these tests, other technical procedures for the treatment of yellowwater (vacuum evaporisation, steam stripping, precipitation, ozonisation, UV irradiation and process combinations) were investigated. The aim of these tests was to gain marketable products.

In the sanitation concept featuring vacuum separation toilets, yellow- und greywater was discharged by gravity, but the brownwater was transported by a vacuum system. The yellowwater was treated as described above. The brownwater from the vacuum separation toilets was treated in a two-stage thermophile biogas plant; at times, bio-waste was added. The digested sludge generated in this process can, on the whole, be used as fertiliser. The further use of the biogas produced in this process was not tested in this project.

The sanitation concept using the gravity separation toilets was tested in an office building in a preliminary project phase from October of 2003 to April of 2005. For these purposes, 10 gravity separation toilets and 5 waterless urinals from 3 different producers were installed. Based on the insights gained in this project phase, in the spring of 2005, gravity separation toilets were installed in 10 apartments in the apartment house. Simultaneously, starting in October 2003, the gravity separation toilets in the office building were gradually replaced with vacuum separation toilets. [8]

The final report of the project is available at: http://www.kompetenzwasser.de/SCST.22.0.html?\&L=1. Because of the short period at the end of the project the digestion of brownwater is still in research in a project with Berliner Wasserbetriebe. 


\section{Tests with brownwater}

The biogas plant in Stahnsdorf is a two stage fixed bed digester with $300 \mathrm{~L}$ volume. The biogas plant is parted in a balancing tank with stirrer and the biogas reactor itself. In thermophile mode the first stage of the biogas plant works as acidification reactor and the second as methanogenic. For mesophile mode the fixed bad was removed. The brownwater from the office building runs to the balancing tank. Settled volume was loaded to the biogas plant.

The calculated load including bio waste was up $1.5 \mathrm{~kg} \mathrm{COD} / \mathrm{d}$. Due to a hydraulic retention time of minimum 6 days in thermophile process and an amount of about 1.5 litres flush water per flush effectively a load of $0.5 \mathrm{~kg}$ $\mathrm{COD} / \mathrm{d}$ was up to now reachable. After the operation with the thermophilic mode the thermophile operating mode was changed into mesophile operating mode. The advantages and disadvantages of the two different operating modes are shown in table 2 .

Table 2: Advantages/disadvantages of thermophile/mesophile operating mode of the biogas plant.

\begin{tabular}{|l|l|l|}
\hline & Thermophile $\left(55^{\circ} \mathrm{C}\right)$ & Mesophile $\left(35^{\circ} \mathrm{C}\right)$ \\
\hline Disinfection & possible & not possible \\
\hline HRT & about 10 days & about 20 days \\
\hline Biogas production & higher & lower \\
\hline Process stability & lower & higher \\
\hline Energy demand & higher & lower \\
\hline Experiences & less & more \\
\hline Complexity & higher & lower \\
\hline
\end{tabular}

In both modes the brownwater was settled before loading the biogas plant. After settlement $36 \%$ (with low solids) overflows to a buffer and $64 \%$ (with high solids) was the feed for the biogas plant. That was on average $45 \mathrm{~L} / \mathrm{d}$. Concentration of dry residues was about $4 \mathrm{~g} / \mathrm{kg}$, the load was $180 \mathrm{~g} / \mathrm{d}$. The hydraulic retention time of thermophile mode was 6.8 days. In this period the biogas plant produced $639 \mathrm{~L}$ biogas $/ \mathrm{kg}$ vDRinput or rather $313 \mathrm{~L} \mathrm{CH}_{4} / \mathrm{kg}$ vDRinput (see Figure 6). 49\% of the volatile dry matter (vDR) and $72 \%$ auf the chemical oxygen demand (COD) were degraded in the digestion process. In the mesophile mode the quantity of biogas was lower $\left(337 \mathrm{~L}\right.$ biogas $/ \mathrm{kg} \mathrm{vDR}_{\text {input }} /$ $249 \mathrm{~L} \mathrm{CH}_{4} / \mathrm{kg}$ vDR input but quality $\left(\mathrm{CH}_{4}\right.$-content) was higher. 


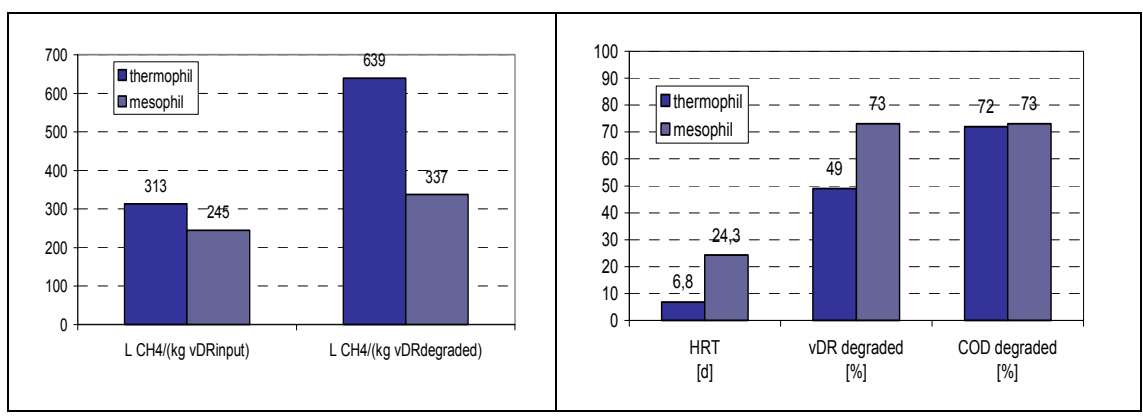

Figure 6: Results of tests in mesophile and thermophile mode.

The hydraulic retention time increased to 24.3 days. While content of degraded COD was stable at $73 \%$, degraded vDR ratio increased to $73 \%$. The improved degradation seems to correlate with the nearly fourfold retention time.

First orientating thermophile tests with bio-waste as co-substrate has shown promising results. The specific biogas production increased to $339 \mathrm{~L} \mathrm{CH}_{4} / \mathrm{kg}$ $\mathrm{vDR}_{\text {input }}$ under nearly same conditions.

Because of the need for space thermophile digestion seems to be the better mode for biogas production in digesters for brownwater. If there are no requirements regarding space for the biogas plant mesophile runs more stable and the degree of degradation is better than in thermophile mode

\section{Conclusions and future aspects}

Novel sanitary systems are positive tested for application in developing or newly industrialising countries. But they are applicable for high-density areas in industrialised countries and not only to sparsely populated areas without existing sewer systems. An enormous amount of old sewer systems must be reconstructed within the next few decades in the most industrialised countries. Otherwise resources like phosphorous and fossil fuels decrease more and more. Wastewater is full of energy and nutrients. Urine fertiliser is a good substitute to mineral fertiliser. By the maintenance of sanitary standards there is good acceptance for novel sanitary systems.

The construction of conventional sanitary systems (end-of-pipe-system) especially in arid areas is not useful. Due to the ubiquitary water shortage sewers are not an intelligent solution. The financing of those systems in the majority of cases is not possible. Novel sanitary systems give the possibility to use water and nutrients sustainable as a resource through water reuse, energy production and fertiliser substitution.

Because of no water shortage in Middle Europe novel sanitary systems were considered as an export business for developing countries and sometimes for sparsely populated areas in developed countries. But new sanitary systems can also be implemented in peri-urban and urban areas with a high density of population. Interesting use cases can be rapidly growing mega-cities with no or 
with lacking in wastewater infrastructure. For instance in South America and South-East Asia are many problems with collection and treatment of wastewater. Waste water systems if even existing are overloaded. The insufficient wastewater treatment causes diseases and increasing environmental pollution. Nutrients in wastewater can substitute cost-expensive mineral fertilisers. In those regions fertiliser is a scare commodity. Sludge to fertiliser is good for safeguarding of resources.

CO2-emission will be reduced by production and using of biogas and by substitution of high energy produced mineral fertiliser.

The implementation of alternative sanitary systems in multi-storey buildings of urban areas is principally possible but some more research for instance regarding adaption of SBR and membrane plant into the system is necessary.

Alternative sanitary systems are a close alternative to the conventional urban sewer systems.

\section{References}

[1] FBR, Fachvereinigung Betriebs- und Regenwassernutzung fbrWasserspiegel 02/06, fbr Dialog GmbH, Darmstadt 2006, modified

[2] ATT et al. [Hrsg.] (2008). Branchenbild der deutschen Wasserwirtschaft 2008, Arbeitsgemeinschaft Trinkwassertalsperren e. V. und andere, wvgw Wirtschafts- und Verlagsgesellschaft Gas und Wasser mbH, Bonn 2008

[3] DWA, Neuartige Sanitärsysteme, Deutsche Vereinigung für Wasserwirtschaft, Abwasser und Abfall; 1. Auflage, Hennef 2008

[4] Höglund, C. Evaluation of microbial health risks associated with the reuse of source-separated human urine. Royal Institute of Technology (KTH), Department of Biotechnology, Applied Microbiology and Swedish Institute of Infectious Disease Control (SMI), Department of Water and Environmental Microbiology, Stockholm 2001

[5] Oldenburg, M., speech at Conference of Department of Urban Water management, University of Rostock 2005

[6] U.N. POPULATION DIVISION 2009, homepage: www.unpopulation.org 19.01.2009

[7] Roediger (2006): Roediger No Mix-Toilette, Vakuumsanitärtechnik, Separationstoiletten Ecosan, Datenblätter, www.roevac.com 18.01.2009

[8] Peter-Fröhlich, A. et al., Sanitation Concepts for Separate Treatment of Urine, Faeces and Greywater (SCST) - Results, Kompetenzzentrum Wasser gGmbH, Berlin 2007 